\title{
A Hamblin Semantics for Evidentials
}

\author{
Sarah E. Murray \\ Rutgers University
}

\section{Introduction}

When speakers enter a conversation, they do so with a shared body of information. As the participants in the conversation speak, what they say affects this common ground. But how exactly is the common ground affected by what they assert? On one view, an assertion updates the common ground (Karttunen 1974, Stalnaker 1975, 1978). A second view is that an assertion is a proposal to update the common ground. This is the view taken in recent work on Inquisitive Semantics (e.g., Groenendijk 2009) and inspired by earlier work on the information structure of discourse (Ginzburg 1996, Roberts 1996, Gunlogson 2001).

What the conversational participants say contains elements which are associated with various kinds of meanings. One distinction that has been made is between the at-issue content of an utterance, the 'main point', and the content which is not at-issue (Potts 2005, Papafragou 2006, Simons 2007, Amaral et al. 2007). This distinction has been used to analyze various phenomena, including some parentheticals, parenthetical uses of embedding verbs, and epistemic modals.

In this paper, I propose that the distinction between what is at-issue and what is not can be modeled as a distinction between two components of assertion. These two components affect the common ground in different ways. The at-issue component of an assertion, which is negotiable, is treated as a proposal to update the common ground. The not-at-issue component of an assertion, which is not negotiable, is added directly to the common ground.

Evidence for this proposal comes from evidentials, which I argue grammaticize this distinction. It has been observed that sentences with evidentials make both an 'evidential' and a 'propositional' contribution (Faller 2002, 2006, Matthewson et al. 2008). The evidential contribution is not directly challengeable or up for negotiation. In contrast, the propositional contribution, the 'main point' of the sentence, is directly challengeable and up for negotiation. I analyze these two contributions of evidentials as the not-at-issue component of assertion and the at-issue component of assertion, respectively. Supporting data comes from Cheyenne, a language with evidentials that are part of the illocutionary mood paradigm.

I am grateful to the following people for helpful comments and discussion: Maria Bittner, Roger Schwarzschild, Matthew Stone, Jeroen Groenendijk, Jason Stanley, William Starr, participants at SALT XIX, SULA 5, the Rutgers Semantics Reading Group (27 March 2009), and in the Rutgers Semantics Seminar on Speech Acts (Fall 2008). I am also grateful to my Cheyenne consultants, and others I have talked with about Cheyenne, for their collaboration and discussion of Cheyenne data. Fieldwork supported in part by the Endangered Language Fund. All errors are my own. 
This paper is structured as follows. In Section 2, I briefly describe Cheyenne evidentials, which behave like parentheticals in declarative sentences, similar to previously described systems (e.g., in Faller 2002). In Section 3, I analyze evidentials as contributing to the not-at-issue component of assertion. The information contributed by evidentials is new, not presupposed (contra Matthewson et al. 2008). In addition, evidentials are truth-conditional and there is no appeal to a separate level of illocutionary meaning (contra Faller 2002, 2006). In Section 4, I formalize this analysis, building on Hamblin (1973). In Section 5, I compare this approach with some influential alternatives (Faller 2002, Matthewson et al. 2008, Potts 2005).

\section{Cheyenne Evidentials}

Cheyenne $^{1}$ is a Plains Algonquian language spoken in Montana and Oklahoma. There is a four-way evidential distinction in Cheyenne between the unmarked direct evidential and three overtly marked indirect evidentials: the inferential, the reportative, and a restricted reportative. The data and analysis in this paper focuses on examples containing the direct and the (plain) reportative.

\subsection{Illocutionary Mood Paradigm}

In Cheyenne, evidentials are part of the inflectional system (cf., e.g., Cuzco Quechua (Faller 2002) and Kalaallisut (Bittner 2008)). Verbs in Cheyenne have a templatic structure - a fixed number of affix slots in a fixed order - with the outermost suffix slot reserved for a 'mode' suffix. In matrix verbs, this mode slot can be filled with an evidential, e.g., (1a) and (1b), or an illocutionary mood marker, including a yes/no interrogative marker (1c), imperative (1d), or an optative (1e), among others. Cheyenne evidentials can also occur in questions, as in $\left(1 \mathrm{a}^{\prime}\right)$ and $\left(1 \mathrm{~b}^{\prime}\right)$.

(1) Excerpt of Cheyenne illocutionary mood paradigm
a. Direct evidential
É-néméne- $\varnothing$.
$\mathrm{a}^{\prime}$. Direct evidential in a question
3-sing-DIR
Mó=é-néméne- $\varnothing$ ?
'He sang, I'm sure.'
$y / n=3$-sing-DIR
b. Reportative evidential
É-némene-sèstse.
'Given what you know, did he sing?'
3-sing-RPT.3SG
'He sang, I hear.'
$\mathrm{b}^{\prime}$. Reportative evidential in a question
Mó=é-némene-sèstse?
$y / n=3$-sing-RPT.3SG
'Given what you heard, did he sing?'
c. Interrogative
Né-némene-he?
2-sing- $\mathrm{Y} / \mathrm{N}$
'Did you (sg.) sing?'
d. Imperative
Néménè-stse!
e. Optative
sing-IMP.2SG
Némene-ha!
'(You (sg.)) sing!' 'Let him sing!'

${ }^{1}$ The data presented in this paper is primarily from the author's fieldwork, supplemented with paradigms from a Cheyenne Grammar (Leman 1980). 
Cheyenne sentences with a direct evidential, such as (1a), are stronger than unmarked sentences in English. This default, unmarked evidential carries a commitment that the speaker has direct evidence for the proposition in the scope of the evidential, e.g., 'he sang' for (1a). This evidential commitment can best be expressed in English with a parenthetical, as in He sang, I'm sure or He sang, I'm certain. These parentheticals strengthen the assertion, unlike epistemic modals, which intuitively weaken it (despite contributing additional information). This strengthening effect occurs in other languages with evidentials, including Cuzco Quechua for both the unmarked and the marked direct evidential (Faller 2002).

\subsection{Parenthetical-like Behavior}

The declarative use of the Cheyenne evidentials conforms to well-known, crosslinguistic patterns, behaving similarly to parenthetical-like, or 'illocutionary', evidentials in other languages, such as Cuzco Quechua (Faller 2002) ${ }^{2}$. Like English parentheticals, evidentials in such languages cannot take scope under certain operators, e.g., modals and negation. For example, English Dale may be alive, I hear cannot be interpreted as It is possible that I have heard that Dale is alive. That is, the parenthetical cannot be interpreted in the scope of the modal. The same is true of evidentials in Cheyenne. A further parallel with parentheticals is that the evidential contribution of a sentence cannot be directly challenged or denied. In English, the 'propositional' contribution, or 'main point' of a sentence can be directly challenged, but the parenthetical contribution cannot be. For example, Dale likes sugar in his coffee, I hear can be challenged by That's not true, he likes it black! but not by \#That's not true, you didn't hear that! Likewise, (1b) can be challenged by That's not true, he danced! but not by \#That's not true, you didn't hear that!

In languages with parenthetical-like evidentials, the reportative does not commit the speaker to the truth (or falsity) of the proposition in its scope (see, e.g., Faller 2002). In other words, the speaker need not believe the reportative's scope and in fact can assert its negation. This pattern is exemplified by Cheyenne (2), where the speaker has direct evidence to the contrary of what has been reported. ${ }^{3}$

(i) É-hó'tȧheva-sèstse Floyd naa+oha 3-win-RPT.3SG Floyd but (ii) é-sáa-hó'tảhévá-he- $\varnothing$. 3-NEG-win- $h($ an $) e$-DIR

'Floyd won, I hear, but I'm certain he didn't.'

The generalization exemplified by (2) is not true of reportatives in all languages. For example, in St'át'imcets, which has modal-like evidentials, the speaker is committed to (at-least) the possibility of the reportative's scope (Matthewson et al. 2008).

In Cheyenne, though the speaker is not committed to the truth of the reportative's scope, she is committed to having reportative evidence for it. That is,

\footnotetext{
${ }^{2}$ Notable exceptions are the behavior of Cheyenne evidentials in questions (see Murray to appear) and that the Cheyenne reportative is limited to secondhand reports.

${ }^{3}$ Examples (2) - (4) adapted from Cuzco Quechua data given in Faller $(2002,2006)$.
} 
the speaker cannot deny that there was a reporting event where she received the information in the reportative's scope, as illustrated by Cheyenne (3).

$$
\begin{aligned}
& \#_{\perp} \text { (i) É-hó'täheva-sėstse Floyd naa+oha (ii) ná-sáa-néstomóné-he- } \varnothing \text {. } \\
& \text { 3-win-RPT.3SG Floyd but } \\
& \#_{\perp} \text { 'Floyd won, I hear, but I didn't hear that.' }
\end{aligned}
$$

Cheyenne (3) is not merely infelicitous - it is intuitively contradictory (\# $\left.\#_{\perp}\right)$, like the English gloss. As far as I know, the generalization exemplified by (3), that the report is not deniable, holds for reportatives cross-linguistically.

Unlike the Cheyenne reportative, the direct evidential commits the speaker to the truth of the scope proposition, as in (4), which is a contradiction.

$$
\begin{aligned}
& \#_{\perp} \text { (i) É-hó'tảhéva- } \varnothing \text { Floyd naa+oha (ii) é-sáa-hó'tảhévá-he- } \varnothing \text {. } \\
& \text { 3-win-DIR Floyd but 3-NEG-win-h(an)e-DIR } \\
& \#_{\perp} \text { 'Floyd won, I'm sure, but I'm certain he didn't.' }
\end{aligned}
$$

\section{Evidentials as Not-At-Issue Assertion}

An assertion has the potential to change the common ground ${ }^{4}$. Stalnaker (1975: Appendix) treats (the essential effect of) an assertion as the intersection of two sets of worlds: the proposition expressed and the input common ground. The rejection of an assertion is treated as blocking this effect, leaving the input common ground unchanged (Stalnaker 1975, 1978). On another view, an assertion is a proposal to update the common ground (Groenendijk 2009) ${ }^{5}$. If the proposal is accepted, i.e., if nobody objects, then the proposition expressed is added to the common ground.

I treat assertion as having two components, the at-issue and the not-at-issue, each with its own effect on the common ground. The at-issue component of assertion is treated as a proposal to update the common ground while the not-at-issue component is treated as updating the common ground simpliciter ${ }^{6}$. I formalize the notion of a proposal as a structured set of worlds: the pair of a common ground and an ordering relation on that set (cf. Groenendijk 2009). If the proposal is accepted, the set of top-ranked worlds becomes the new common ground. This new common ground contains only worlds that were members of the initial common ground where the proposition expressed is true. As an example, consider English (5).

\footnotetext{
${ }^{4}$ I take the common ground to be the information that the conversational participants take for granted (or act as though they do) for the sake of the conversation, regardless of what they actually believe (following, e.g., Stalnaker 1978). Here, the common ground is treated as the intersection of a set of propositions - a set of worlds - by some terminologies the 'context set'.

${ }^{5}$ See also work on the structure of discourse (Ginzburg 1996, Roberts 1996, Gunlogson 2001).

${ }^{6}$ This not-at-issue component of assertion has an effect similar to what Stalnaker (1978) calls the commonplace effect: the addition of certain new information to the common ground (e.g., who is speaking, what words she is using). This information updates the common ground, but it is not negotiable and cannot be directly challenged or denied. It is added to the common ground even if the essential effect is denied. However, the commonplace effect is pragmatic. It does not reflect the contribution of part of the sentence itself, a morpheme or phrase, as is the case with evidentials.
} 
The proposition expressed by an (assertive) utterance of (5) is the proposition that Floyd won. This proposition, call it $p$, is the at-issue content of (5). The proposal to add $p$ to the common ground yields a structured set of worlds: the initial common ground $c_{0}$ and the ordering relation $\leq_{p}$, which orders $p$-worlds over $\neg p$ worlds. This is depicted in Figure 1, where worlds which are still live possibilities are shaded grey; preferred worlds are represented by a darker grey.

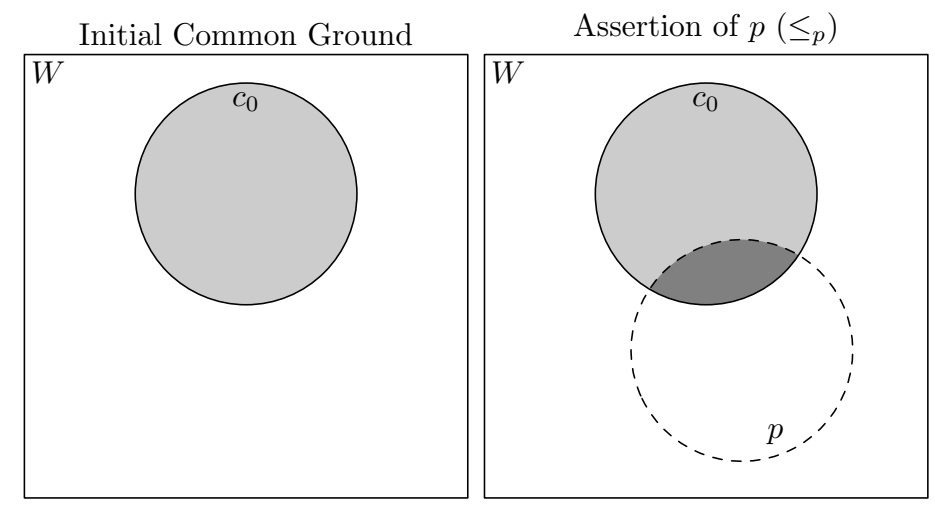

Figure 1: The contribution of (5): Floyd won

This approach represents the fact that the proposition expressed by (5) is negotiable, that it can be directly challenged and denied. For example, when a speaker utters (5), her interlocutors may object: No he didn't! or That's not true, Albert won! In contrast, the not-at-issue component of assertion, which cannot be directly challenged nor denied, would directly update the common ground. For the present purposes, I treat (5) as not having, or having an empty, not-at-issue component. In the remainder of this section, I present an analysis of sentences with evidentials that makes use of this distinction in assertion.

\subsection{The Direct Evidential}

It has been well argued in the literature that sentences with evidentials make both a 'propositional' contribution and an 'evidential' contribution, and that these two contributions need to be distinguished (Faller 2002, Matthewson et al. 2008, see also Section 2, above). For example, an assertive utterance of Cheyenne (6), which contains the direct evidential, makes both of these contributions.

$$
\begin{array}{ll}
\text { É-hó'tảhéva- } \varnothing & \text { Floyd. } \\
\text { 3-win-DIR } & \text { Floyd } \\
\text { 'Floyd won, I'm sure.' }
\end{array}
$$

The propositional contribution of (6) is the utterance's main point - that Floyd won. It is comparable to the contribution of unmarked English sentences, such as (5). In 
(6), the proposition that Floyd won is the negotiable contribution of the sentence. When a speaker utters (6), she proposes to add the information that Floyd won to the common ground. However, her interlocutors may felicitously object: No he didn't! or That's not true! Floyd didn't win, it was Albert!

The evidential contribution of (6) indicates that the speaker has direct evidence for the proposition in the evidential's scope. It entails that the speaker is certain based on personal experience of the scope proposition. The evidential contribution not up for negotiation. It cannot be directly challenged or denied. For example, it is infelicitous to reply to (6) with No you aren't! or No you don't! However, the evidential contribution is new information that reduces the common ground, not information which is presupposed, or cancellable.

I propose that Cheyenne sentences with evidentials be analyzed as encoding a distinction in assertion between what is at-issue and what is not. The evidential contribution is the not-at-issue component - it restricts the common ground, but is not negotiable. The at-issue component is the propositional contribution, the negotiable proposal to add the proposition expressed to the common ground.

I call these two contributions of sentences with evidentials the EVIDENTIAL RESTRICTION and the ILLOCUTIONARY RELATION ${ }^{7}$, respectively. For (6), the evidential restriction reduces the input common ground $c_{0}$ to the worlds where the speaker $i$ is certain (based on personal experience) of the proposition $p$ that Floyd won (written as $\operatorname{CRT}(i, p)$, shown in Figure 2, below). This analysis is consistent with the idea that the evidential is the 'grounds for making a speech act' (Faller 2002). The new common ground is $c_{1}$, the intersection of $c_{0}$ and $C R T(i, p)$.
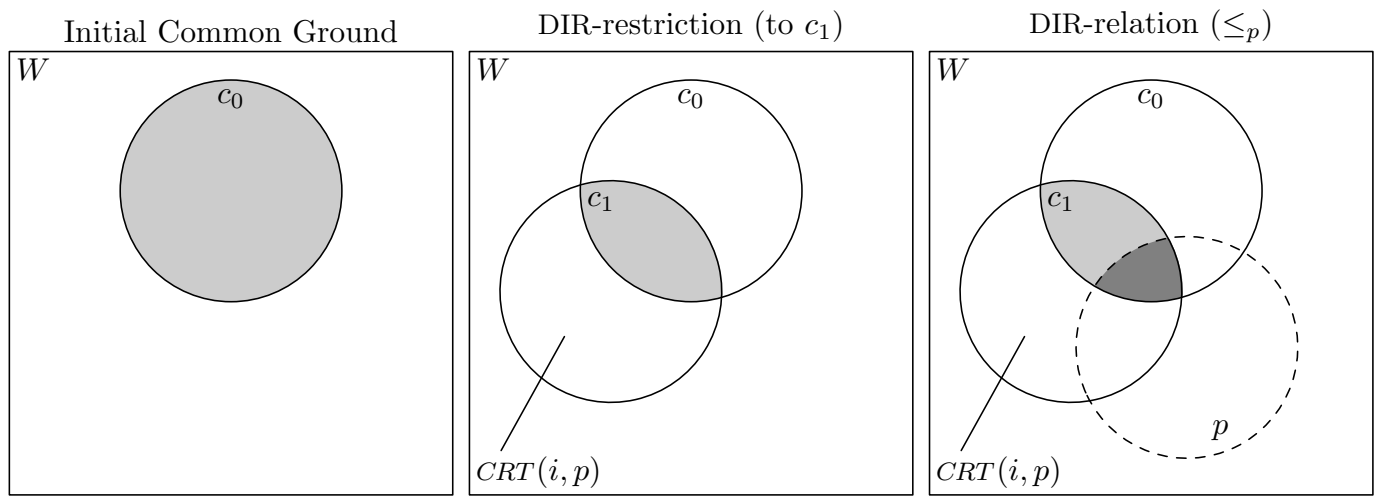

Figure 2: The two contributions of (6): 3-win-DIR Floyd

The illocutionary relation contributed by the direct evidential in (6) represents the proposal to add to the restricted common ground the at-issue proposition $p$, the proposition that Floyd won. I propose to model this illocutionary relation as an ordering relation on the current context $c_{1}$ which orders the $p$-worlds in $c_{1}$ over the

\footnotetext{
${ }^{7}$ The choice of evidential has an effect on the content of the proposal, so I might have called this contribution the EVIDENTIAL RELATION. However, Cheyenne evidentials are part of the illocutionary mood paradigm and in related work I argue that other mood markers also contribute a type of proposal, formalized as a different sort of relation (see Murray to appear).
} 
$\neg p$-worlds in $c_{1}:\left\langle c_{1}, \leq_{p}\right\rangle$. The output is a common ground that is restricted (by the evidential restriction) and structured (by the illocutionary relation). If the proposal to add $p$ to the common ground is accepted, the set of the top-ranked $c_{1}$ worlds (darker grey) will become the new common ground, eliminating all $\neg p$-worlds.

\subsection{The Reportative Evidential}

Sentences with the reportative evidential also make two contributions. For example, consider Cheyenne (7), which may be used in a variety of situations, like the English translation, but is limited to second hand reports. A speaker would use (7) if they were told (6), read it in a newspaper, overheard it, and so on. However, it would not be felicitous for one speaker to repeat (7) if she had heard (7) from someone else, read it, et cetera. In this case she would use a different indirect evidential.

$$
\begin{aligned}
& \text { É-hó'tảheva-sèstse Floyd. } \\
& \text { 3-win-RPT.3SG Floyd } \\
& \text { 'Floyd won, I hear.' }
\end{aligned}
$$

Sentences with a reportative evidential are analyzed in parallel to ones with a direct evidential: they contribute an evidential restriction and an illocutionary relation. The at-issue proposition in (7) is the same as in (6): $p$, that Floyd won. The evidential restriction of (7) reduces the input common ground $c_{0}$ to worlds where the speaker heard the at-issue proposition $p$ (written $H R D(i, p)$, in Figure 3). This contribution is not-at-issue and non-negotiable.
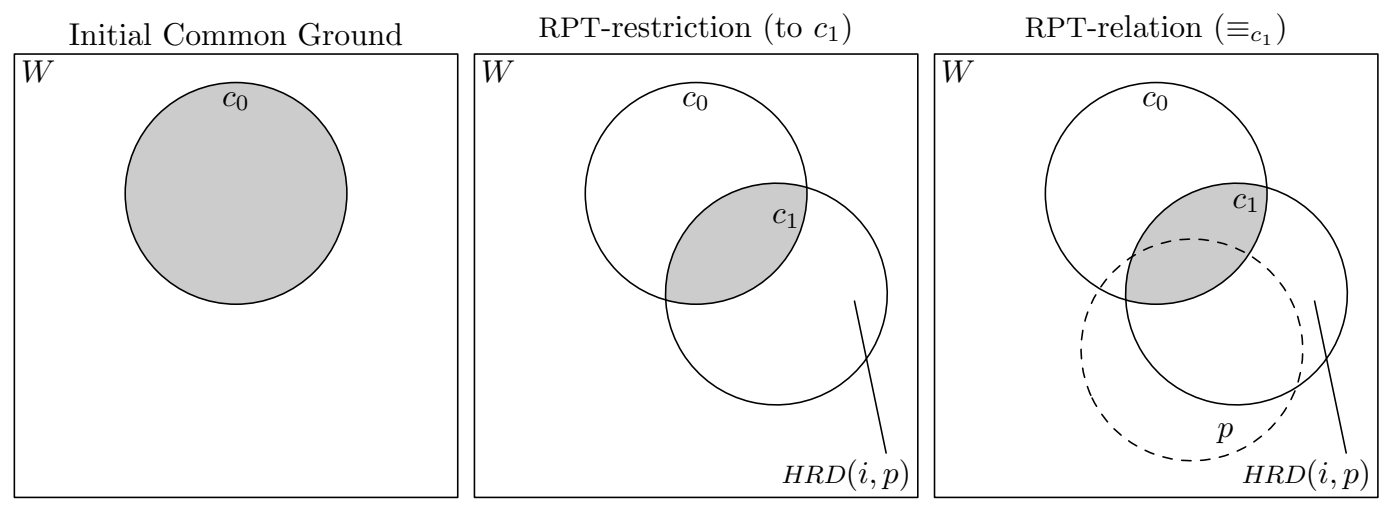

Figure 3: The two contributions of (7): 3-win-RPT.3SG Floyd

Unlike the direct evidential, the illocutionary relation contributed by a reportative is not the proposal to add the at-issue proposition to the common ground. Instead, the proposal is to take note of the at-issue proposition, here, $p$, that Floyd won, but for the common ground to remain unchanged. I propose to represent this as an equivalence relation that ranks all input common ground worlds on a par: $\left\langle c_{1}, \equiv c_{1}\right\rangle$. In particular, $p$-worlds and $\neg p$-worlds are equally preferred.

If the proposal is accepted, the new common ground will become the set of top-ranked worlds. However, since all of the worlds are top-ranked, the current 
common ground $\left(c_{1}\right)$ will remain unchanged. This analysis of the reportative is intended to capture the intuition that a proposition in the scope of a reportative evidential is 'presented' by the speaker (Faller 2002) and is not proposed to be added to the common ground. However, the present analysis need not appeal to a new type of speech act to account for this (see Section 5). In addition, it can capture the felicity of conjunctions like (2), as is discussed in the next section.

\subsection{Conjunctions as Sequential Update}

In languages with parenthetical-like evidentials, the scope of the reportative can be false (see Section 2.2). Thus, sentences like (2), repeated below, are felicitous.

$$
\begin{array}{lll}
\text { (i) É-hó'tảheva-sėstse } & \text { Floyd naa+oha (ii) é-sáa-hó'tảhévá-he- } \varnothing . \\
\text { 3-win-RPT.3SG } & \text { Floyd but } & \text { 3-NEG-win- } h(a n) e-D I R
\end{array}
$$

'Floyd won, I hear, but I'm certain he didn't.'

Each conjunct of (2) contains its own evidential. Following the standard in dynamic semantics, I interpret conjunctions as sequential update: the second conjunct is interpreted not in the original context but in the output of the first conjunct (Groenendijk and Stokhof 1991, Veltman 1996, Muskens 1996). The analysis of (2i) was given above (Figure 3, Section 3.2). The output is a common ground restricted to worlds where the speaker heard the proposition $p$, that Floyd won, and structured into one cell containing all $c_{1}$ worlds, both $p$-worlds and $\neg p$-worlds: $\left\langle c_{1}, \equiv_{c_{1}}\right\rangle$.

The second conjunct (2ii) contains a direct evidential and contributes its own evidential restriction and illocutionary relation. The evidential restriction reduces the common ground $c_{1}$ to the set of worlds where the speaker is certain, based on direct evidence, that $\neg p$, that Floyd did not win (written $C R T(i, \neg p)$ in Figure 4).

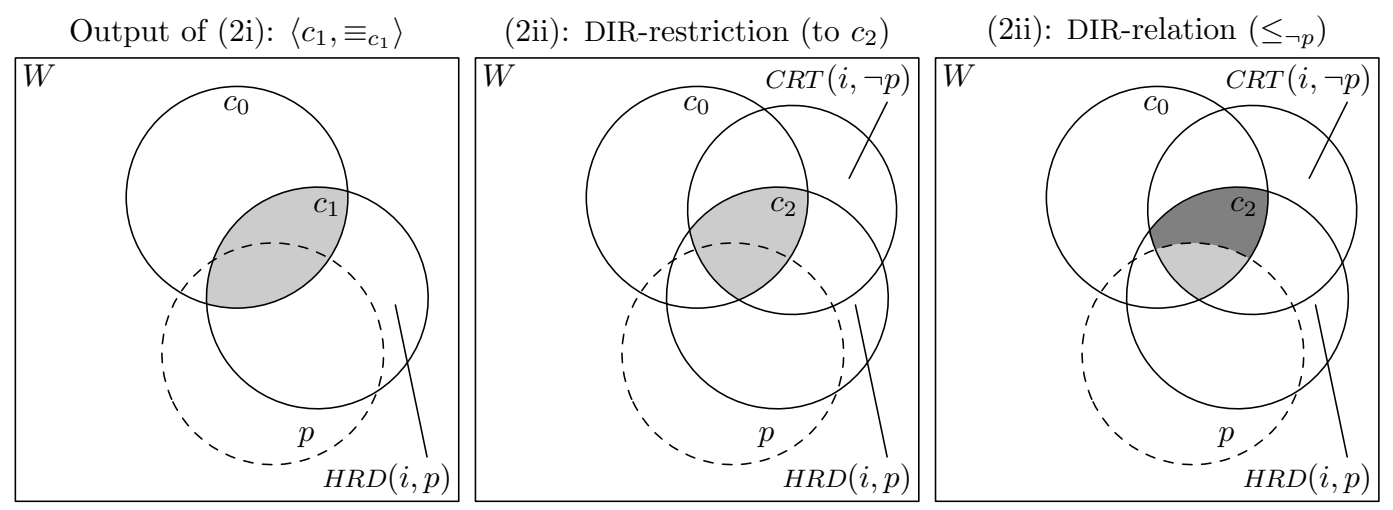

Figure 4: Felicitous conjunction of (2i) and (2ii)

The illocutionary relation is the proposal to add to the common ground the at-issue proposition, here, $\neg p$, that Floyd did not win. I represent this as an ordering relation on the current context, $c_{2}$, where $\neg p$-worlds are preferred over $p$-worlds: $\left\langle c_{2}, \leq_{\neg p}\right\rangle$. If the proposal is accepted, the resulting common ground will consist of $c_{0}$ worlds 
where the speaker heard that $p\left(c_{1}\right)$, is certain that $\neg p\left(c_{2}\right)$, and where $\neg p$ is true (top-ranked $c_{2}$ worlds under $\leq_{\neg p}$ ). Normally, that sequence of updates yields a non-empty common ground, so the conjunction is felicitous.

Infelicitous conjunctions involve incompatible updates, resulting in an output common ground that is necessarily empty - the absurd state. An example of such a conjunction is Cheyenne (4), which shows that, unlike in (2) with the reportative evidential, the speaker is committed to the direct evidential's scope.

$$
\begin{array}{ccc}
\#_{\perp} \text { (i) É-hó'tảhéva- } \varnothing & \text { Floyd naa+oha (ii) é-sáa-hó'tảhévá-he- } \varnothing . \\
\text { 3-win-DIR } & \text { Floyd but } & \text { 3-NEG-won- } h \text { (an)e-DIR } \\
\#_{\perp} \text { 'Floyd won, I'm sure, but I'm sure he didn't.' }
\end{array}
$$

Cheyenne (4) is a contradiction: the speaker denies in the second conjunct what she asserts in the first. Both conjuncts contain a direct evidential. The output of (4i) is a common ground $c_{1}$ restricted to worlds where the speaker is certain that Floyd won and structured by a relation that ranks $p$-worlds over $\neg p$-worlds, written $\left\langle c_{1}, \leq_{p}\right\rangle$ (see Figure 2, Section 3.1).

The second conjunct (4ii) contributes its own evidential restriction and illocutionary relation. The evidential restriction reduces the common ground $c_{1}$ to the set of worlds where the speaker is certain that $\neg p$, that Floyd did not win (written $\operatorname{CRT}(i, \neg p)$ in Figure 5). The resulting common ground $c_{2}$ is one where the speaker is certain, based on direct evidence, that Floyd won and is also certain, based on direct evidence, that he did not win. This is probably already an empty set of worlds. In the unlikely case that any worlds remain in the common ground $c_{2}$, as in Figure 5 , the contribution of the illocutionary relation will rule them out.
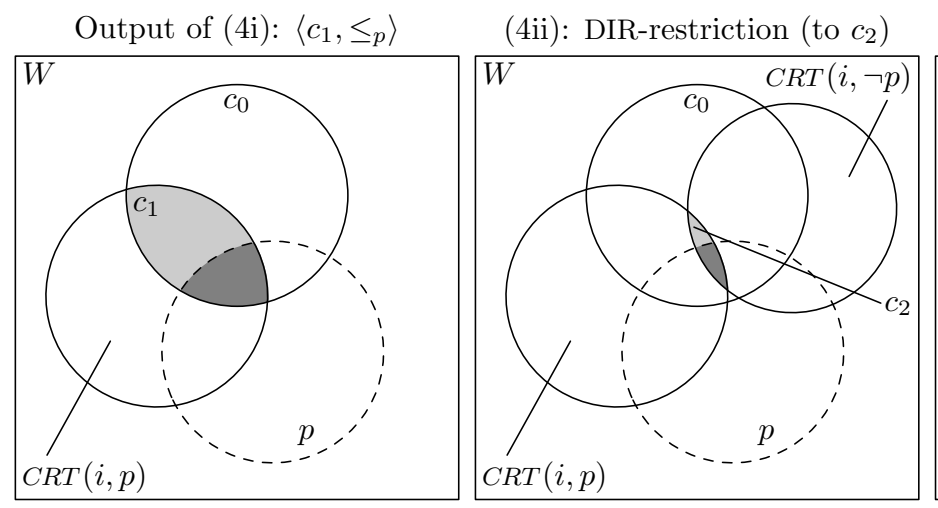

(4ii): DIR-relation $\left(\leq_{\neg p}\right)$

Figure 5: Infelicitous denial in (4ii) of (4i)

The illocutionary relation of (4ii) is the proposal to add to the common ground the at-issue proposition, here, $\neg p$, that Floyd did not win. This is represented as an ordering relation on the current context, $c_{2}$, where $\neg p$-worlds in $c_{2}$ are preferred over $p$-worlds in $c_{2}$. However, this is incompatible with the relation contributed by (4i), which ordered $p$-worlds over $\neg p$-worlds. The proposals of the two conjuncts contradict each other. In short, any context which supports (4i) cannot support (4ii). 


\section{Formal Implementation}

Hamblin (1973) analyzes English interrogatives like (8a) within Montague Grammar as sets of propositions, the set of possible direct answers, as in (8b), given in $\mathrm{Ty}_{2}$ (Gallin 1975). To unify the rules for semantic composition and maintain a category to type correspondence, declarative sentences like (9a) are assimilated to this type of semantic object, analyzed as singleton sets of propositions, as in (9b).

a. Who won?

b. $\quad \lambda p[\exists x(\operatorname{person}(x) \wedge(p=\lambda w \cdot w o n(w, x)))]$

a. Floyd won.

b. $\quad \lambda p[p=\lambda w[$ won $(w$, floyd $)]]$

Translations (8b) and (9b) each represent (the characteristic function of) a set of propositions. The identity condition in each specifies which propositions, if any, are eligible to make it into the set. In the translation of the interrogative in (8b), the first conjunct imposes an additional restriction on this set: that $\mathrm{x}$ be a person.

I propose to build on Hamblin's (1973) treatment of sentences as sets of propositions to distinguish the two contributions of sentences with evidentials. The key division is between what is part of the identity condition and what is a further restriction on the set of propositions. Consider Cheyenne (6) from Section 3.1, repeated below, and its proposed translation in $\left(6^{\prime}\right)$.

$$
\begin{array}{ll}
\text { É-hó'tȧhéva- } \varnothing & \text { Floyd. } \\
\text { 3-win-DIR } & \text { Floyd } \\
\text { 'Floyd won, I'm sure.' }
\end{array}
$$

(6') Hamblin-style representation of (evidential) declarative:

$$
\begin{array}{ccc}
\lambda \mathrm{p}[(\mathrm{p}=\lambda \mathrm{w}[\text { won }(\mathrm{w}, \text { floyd })]) & \wedge \mathrm{CRT}\left(\mathrm{v}_{0}, \mathrm{i}, \mathrm{p}\right) & \left.\wedge \mathrm{p}\left(\mathrm{v}_{0}\right) \leq \mathrm{p}\left(\mathrm{v}_{1}\right)\right] \\
\hline \text { (at-issue proposition) } & (\text { ev. restriction }) & \text { (ill. relation) }
\end{array}
$$

The set characterized by $\left(6^{\prime}\right)$ is the singleton of the at-issue proposition if each condition is met, the empty set otherwise. Parallel to Hamblin's (1973) identity conditions in (8b) and (9b), the first conjunct of $\left(6^{\prime}\right)$ identifies the proposition that is eligible to make it into the set. This proposition is the scope of the evidential the at-issue proposition or 'main point'. The second and third conjuncts in $(6$ '), the evidential restriction and illocutionary relation, are further restrictions on this set of propositions, similar to the person restriction in (8b).

The two free variables in $\left(6^{\prime}\right), v_{0}$ and $v_{1}$, are used to define the evidential restriction and illocutionary relation. The evidential restriction is defined in terms of an update function by binding the variable $v_{0}$. The illocutionary relation, modeled as a relation on the restricted common ground, is defined by binding both $v_{0}$ and $v_{1}$.

In the remainder of this section, I look in turn at sentences with direct evidentials, sentences with reportatives, and the conjunctions of such sentences. The representation for each sentence is given, as are the rules for interpretation. These formalizations make precise the analysis given in Section 3. 


\subsection{The Direct Evidential}

The translation of sentence (6) is repeated below in $\left(6^{\prime}\right)$. The first conjunct represents the at-issue proposition, the scope of the evidential. In (6), the at-issue proposition is the proposition that Floyd won. The second conjunct in $\left(6^{\prime}\right)$ represents the evidential restriction. This is the evidential contribution, that the speaker is certain, based on direct evidence, that Floyd won. The final condition is the illocutionary relation. In $\left(6^{\prime}\right)$, the illocutionary relation represents the proposal to add the at-issue proposition to the common ground by ordering worlds where the at-issue proposition is true over worlds where it is not.

$$
\lambda \mathrm{p}\left[(\mathrm{p}=\lambda \mathrm{w}[\mathrm{won}(\mathrm{w}, \text { floyd })]) \wedge \mathrm{CRT}\left(\mathrm{v}_{0}, \mathrm{i}, \mathrm{p}\right) \wedge \mathrm{p}\left(\mathrm{v}_{0}\right) \leq \mathrm{p}\left(\mathrm{v}_{1}\right)\right]
$$

So far, this implementation does not say anything about context change. However, an elementary update operation which represents the evidential restriction can be defined by binding the world variable $v_{0}$, as in Definition 1 .

Definition 1 (Evidential Restriction). For a common ground $c$, a model $\mathcal{M}$, and an $(s t) t$ term $P, c$ updated with $P$ is defined as:

$$
c[P]=\left\{w \in c \mid \exists g \exists p \in D_{s t}\left(\llbracket \lambda v_{0}[P] \rrbracket^{\mathcal{M}, g}(w)=\{p\}\right)\right\}
$$

This definition takes an input common ground and returns the subset where the not-at-issue assertion is true. If we apply this to $\left(6^{\prime}\right)$, we get result in (10).

$$
\begin{aligned}
c_{0}\left[\left(6^{\prime}\right)\right] & =\left\{w \in c_{0} \mid \exists g \exists p \in D_{s t}\left(\llbracket \lambda v_{0}\left[\left(6^{\prime}\right)\right] \rrbracket^{\mathcal{M}, g}(w)=\{p\}\right)\right\} \\
& =\left\{w \in c_{0} \mid \llbracket \mathrm{CRT} \rrbracket^{\mathcal{M}}(w)\left(\llbracket i \rrbracket^{\mathcal{M}}\right)\left(\llbracket \lambda \mathrm{w}[\mathrm{won}(\mathrm{w}, \text { floyd })] \rrbracket^{\mathcal{M}}\right)=1\right\} \\
& =c_{1}
\end{aligned}
$$

Sentence (6) interpreted in context $c_{0}$ yields $c_{1}$, the restriction of $c_{0}$ to worlds where the speaker is certain, based on personal experience, that Floyd won. Given Definition 1 , the final conjunct of $\left(6^{\prime}\right), p\left(v_{0}\right) \leq p\left(v_{1}\right)$, which specifies the content of the illocutionary relation, contributes a trivial requirement and here can be eliminated.

The illocutionary relation on the restricted common ground can be defined by binding both of the free variables $v_{0}$ and $v_{1}$, as in Definition 2 .

Definition 2 (Illocutionary Relation). For a common ground $c$, worlds $w, w^{\prime}$ in $c$, a model $\mathcal{M}$, and an $(s t) t$ term $P, w$ is $P, c$-related to $w^{\prime}$, written $w \mathcal{R}_{c, P} w^{\prime}$, iff:

$$
w, w^{\prime} \in c \& \llbracket \lambda v_{0} \lambda v_{1}[P] \rrbracket^{\mathcal{M}}(w)\left(w^{\prime}\right) \neq \varnothing
$$

Definition 2 relates worlds in the input common ground according to the nature of the illocutionary relation, which depends on the morpheme that contributes it. In the examples, I replace $\mathcal{R}$ with $\leq$ or $\equiv$ depending on the properties of the relation. When applied to $\left(6^{\prime}\right)$, the result is an ordering relation, given in (11).

$$
\begin{aligned}
& w \leq_{c_{1},\left(6^{\prime}\right)} w^{\prime} \quad \text { iff } \quad w, w^{\prime} \in c_{1} \& \llbracket \lambda v_{0} \lambda v_{1}\left[\left(6^{\prime}\right) \rrbracket^{\mathcal{M}}(w)\left(w^{\prime}\right) \neq \varnothing\right. \\
& \text { iff } \quad w, w^{\prime} \in c_{1} \& \llbracket \lambda w[\text { won }(\mathrm{w}, \text { floyd })] \rrbracket^{\mathcal{M}}(w) \\
& \leq \llbracket \lambda w[\text { won }(w, \text { floyd })] \rrbracket^{\mathcal{M}}\left(w^{\prime}\right)
\end{aligned}
$$

The ordering relation in (11) is one that ranks worlds in $c_{1}$ where Floyd won over worlds in $c_{1}$ where Floyd did not win. 


\subsection{The Reportative Evidential}

The translation of (7), which contains a reportative evidential, is given in $\left(7^{\prime}\right)$. The structure of the translation parallels that of the direct evidential in $\left(6^{\prime}\right)$, representing the at-issue proposition, the evidential restriction, and the illocutionary relation.

$$
\begin{aligned}
& \text { É-hó'tảheva-sèstse Floyd. } \\
& \text { 3-win-RPT.3SG Floyd } \\
& \text { 'Floyd won, I hear.' }
\end{aligned}
$$

$$
\lambda p\left[(p=\lambda w[\text { won }(w, \text { floyd })]) \wedge \operatorname{HRD}\left(v_{0}, i, p\right) \wedge v_{1}=v_{1}\right]
$$

The at-issue proposition for (7) is the same as that for (6): the proposition that Floyd won. What differentiates sentences with reportative evidentials from those with direct evidentials is the content of the additional conditions, the evidential restriction and the illocutionary relation. The evidential restriction in $\left(7^{\prime}\right)$ is to worlds where the speaker heard that Floyd won. The illocutionary relation ranks all $c_{1}$ worlds together as an equivalence class. All worlds in $c_{1}$ are equally preferred, representing the proposal to keep the common ground the same. The definitions of evidential restriction and illocutionary relation given in Section 4.1 can be applied to the translation in $\left(7^{\prime}\right)$. The results are (12) and (13), respectively.

$$
\begin{aligned}
& c_{0}\left[\left(7^{\prime}\right)\right]=\left\{w \in c_{0} \mid \llbracket \mathrm{HRD} \rrbracket^{\mathcal{M}}(w)\left(\llbracket i \rrbracket^{\mathcal{M}}\right)\left(\llbracket \lambda w[\text { won }(\mathrm{w}, \text { floyd })] \rrbracket^{\mathcal{M}}\right)=1\right\}=c_{1} \\
& w \equiv{ }_{c_{1},\left(7^{\prime}\right)} w^{\prime} \text { iff } w, w^{\prime} \in c_{1} \& w^{\prime}=w^{\prime}
\end{aligned}
$$

Ideally, the analysis of the reportative would explicitly draw attention to the at-issue proposition $p$. This is not represented in the current formulation: the illocutionary relation is trivial and does not depend on $p$ outside of the evidential restriction. An implementation of the proposed analysis in a framework with propositional discourse referents (e.g., Stone 1999, Brasoveanu 2007, Bittner 2009) could represent drawing attention to $p$ by introducing a discourse referent for $p$.

\subsection{Conjunctions as Sequential Update}

Following the standard treatment of conjunction in dynamic semantics, I treat conjunctions as sequential update: the second conjunct is interpreted in the output of the first. Felicitous conjunctions are analyzed as compatible updates, infelicitous as incompatible updates. Recall conjunction (2) from Section 2.2 above. The first conjunct of (2) is (7), whose output common ground $c_{1}$ is (12), structured by (13). The second conjunct of (2) is translated as (14) (where 'he' is translated as $z_{1}$, assuming $g\left(\mathrm{z}_{1}\right)=\llbracket$ floyd $\left.\rrbracket^{\mathcal{M}}\right)$. Interpreted in the common ground restricted by the first conjunct, $c_{1}$, (14) reduces $c_{1}$ to $c_{2}$ as in (15) and structures $c_{2}$ with (16).

$$
\begin{aligned}
& \lambda \mathrm{p}\left[\left(\mathrm{p}=\lambda \mathrm{w}\left[\neg \mathrm{won}\left(\mathrm{w}, \mathrm{z}_{1}\right)\right]\right) \wedge \mathrm{CRT}\left(\mathrm{v}_{0}, \mathrm{i}, \mathrm{p}\right) \wedge \mathrm{p}\left(\mathrm{v}_{0}\right) \leq \mathrm{p}\left(\mathrm{v}_{1}\right)\right] \\
& c_{1}[(14)]=\left\{w \in c_{1} \mid \llbracket \mathrm{CRT} \rrbracket^{\mathcal{M}}(w)\left(\llbracket i \rrbracket^{\mathcal{M}}\right)\left(\llbracket \lambda \mathrm{w}\left[\neg \mathrm{won}\left(\mathrm{w}, \mathrm{z}_{1}\right)\right] \rrbracket^{\mathcal{M}, g}\right)=1\right\}=c_{2}
\end{aligned}
$$




$$
\begin{aligned}
& w \leq_{c_{2},(14)} w^{\prime} \quad \text { iff } \quad w, w^{\prime} \in c_{1} \& \llbracket \lambda w\left[\neg \text { won }\left(\mathrm{w}, \mathrm{z}_{1}\right)\right] \rrbracket^{\mathcal{M}, g}(w) \\
& \leq \llbracket \lambda \mathrm{w}\left[\neg \mathrm{won}\left(\mathrm{w}, \mathrm{z}_{1}\right)\right] \rrbracket^{\mathcal{M}, g}\left(w^{\prime}\right)
\end{aligned}
$$

This is a compatible sequence of updates: $c_{2}$ in (15) is typically a non-empty set of worlds and the proposals in (13) and (16) are compatible: (2) is felicitous.

Contrast this with Cheyenne (4), which is contradictory. The first conjunct of (4) is (6), which is analyzed in Section 4.1. The output common ground $c_{1}$ is (10), structured by (11), both of which are repeated below.

$$
\begin{gathered}
c_{0}\left[\left(6^{\prime}\right)\right]=\left\{w \in c_{0} \mid \llbracket \mathrm{CRT} \rrbracket^{\mathcal{M}}(w)\left(\llbracket i \rrbracket^{\mathcal{M}}\right)\left(\llbracket \lambda \mathrm{w}[\mathrm{won}(\mathrm{w}, \text { floyd })] \rrbracket^{\mathcal{M}}\right)=1\right\}=c_{1} \\
w \leq_{c_{1},\left(6^{\prime}\right)} w^{\prime} \quad \text { iff } \quad w, w^{\prime} \in c_{1} \& \llbracket \lambda \mathrm{w}[\text { won }(\mathrm{w}, \text { floyd })] \rrbracket^{\mathcal{M}}(w) \\
\leq \llbracket \lambda \mathrm{w}[\text { won }(\mathrm{w}, \text { floyd })] \rrbracket^{\mathcal{M}}\left(w^{\prime}\right)
\end{gathered}
$$

The second conjunct of (4) is the same as the second conjunct of (2), translated as (14). However, when interpreted relative to (10), (14) reduces $c_{1}$ to a typically empty set of worlds: worlds where the speaker is certain, based on direct evidence, that Floyd won and is also certain, based on direct evidence, that Floyd did not win. If any such worlds remain, they will be structured by an illocutionary relation which orders worlds where Floyd did not win over worlds where he won (as in (16)). This relation is necessarily incompatible with (11): (4) is contradictory.

\section{Theory Comparison}

\subsection{Evidentials as Illocutionary Modifiers}

One way evidentials have been analyzed is as illocutionary modifiers, operators which can add to or modify the felicity conditions of a speech act. This type of analysis was developed in Faller (2002) for the parenthetical-like evidentials in Cuzco Quechua, e.g., the direct $=m i$ (in (17) below) and the reportative $=s i$ (in (18)).

$$
\begin{aligned}
& \text { Faller (2002) analysis of Cuzco Quechua direct evidential (p. 167 }{ }^{8} \text { ) }
\end{aligned}
$$

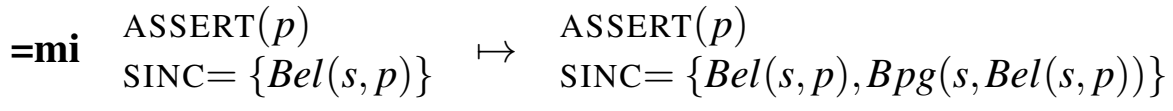

Faller (2002) analysis of Cuzco Quechua reportative evidential (p. 200)

$$
\begin{array}{ll}
=\mathbf{s i} & \operatorname{ASSERT}(p) \\
& \operatorname{SINC}=\{\operatorname{Bel}(s, p)\}
\end{array} \quad \begin{aligned}
& \operatorname{PRESENT}(p) \\
& \operatorname{SINC}=\left\{\exists s_{2}\left(A \operatorname{sisert}\left(s_{2}, p\right) \wedge s_{2} \notin\{h, s\}\right)\right\}
\end{aligned}
$$

On this illocutionary modifier approach, evidentials are functions from speech acts to speech acts. A sentence will have at least as many speech acts as evidentials. ${ }^{9}$ The direct evidential, (17), maps an assertion with the sincerity condition that the

\footnotetext{
${ }^{8}$ The denotation for the Cuzco Quechua direct evidential given in (17) is the one used throughout Faller (2002). A variation, $\operatorname{SINC}=\{\operatorname{Bel}(s, p), \operatorname{Bpg}(s, p)\}$, is given once, in the introduction (p. 25).

${ }^{9}$ A surprising result given certain evidentials can embed (Faller 2002, examples (183) and (213)).
} 
speaker believes $p(\operatorname{Bel}(s, p))$ to an assertion with an added sincerity condition that the speaker has best possible grounds $(B p g)$ for her claim.

Unlike the direct evidential, the reportative evidential, (18), is "destructive" - it eliminates the sincerity condition of the original speech act, replacing it with a new one, and changes the force from an assertion to a 'presentation', a new type of speech act. Intuitively, (18) captures a problematic feature of the reportative: that it does not commit the speaker (either way) to the truth or falsity of the scope proposition. However, the implementation in Faller (2002) requires the introduction of a new speech act primitive. In the present analysis, no new primitive is required to capture this fact. In addition, the illocutionary relation contributed by the reportative fits into a semantic paradigm with the other evidentials and the illocutionary mood markers, e.g., question marking (see Section 2 and Murray to appear).

In Faller (2002), the evidential contribution is analyzed as a sincerity condition. Given this, it is not clear that the analysis makes the correct empirical predictions. For the examples discussed in Section 2, Cuzco Quechua evidentials and Cheyenne evidentials behave equivalently. For example, the scope of the reportative can be false (Faller 2002: 193), but the reporting event is not deniable, as in Cuzco Quechua (19), from Faller (2002: 200, modified translation).

$$
\begin{aligned}
& \text { \# (i) Para-sha-n=si, ichaqa (ii) mana-n willa-wa-rqa-n-chu. } \\
& \text { rain-PROG-3=RPT, but not-DIR tell-1O-PST1-3-NEG }
\end{aligned}
$$

Faller (2002) does not explicitly analyze Quechua (19), and it is not clear what the analysis would predict. As I understand the theory, the conjuncts are not contradictory. The only conflict would be between the sincerity condition of the first conjunct and the asserted propositional content of the second conjunct, predicting that (19) is merely insincere. ${ }^{10}$ This is not strong enough. Cheyenne sentences like (19), e.g., (3), above, are contradictions, just like their English translations. The speaker denies in the second conjunct what she asserts in the first conjunct.

Under the analysis proposed in this paper, Cheyenne (3), translated as $\left(3^{\prime}\right)$, is a contradiction. It is analyzed as an incompatible sequence of updates (instead of multiple speech acts). The first conjunct ( $3^{\prime} i$ ) results in a common ground $c_{1}$ restricted to worlds where the speaker heard the proposition $p$, that Floyd won, and structured by a relation that equally prefers $p$ and $\neg p$-worlds.

$$
\begin{aligned}
\text { i. } & \llbracket \lambda p\left[(p=\lambda w[\text { won }(w, \text { floyd })]) \wedge \operatorname{HRD}\left(\mathrm{v}_{0}, \mathrm{i}, \mathrm{p}\right) \wedge \mathrm{v}_{1}=\mathrm{v}_{1}\right] \rrbracket^{\mathcal{M}, g} \\
\text { ii. } & \llbracket \lambda \mathrm{p}\left[\left(\mathrm{p}=\lambda \mathrm{w}\left[\neg \operatorname{HRD}\left(\mathrm{w}, \mathrm{i}, \mathrm{p}_{1}\right)\right]\right) \wedge \mathrm{CRT}\left(\mathrm{v}_{0}, \mathrm{i}, \mathrm{p}\right) \wedge \mathrm{p}\left(\mathrm{v}_{0}\right) \leq \mathrm{p}\left(\mathrm{v}_{1}\right)\right] \rrbracket^{\mathcal{M}, g} \\
& \left(\text { where } g\left(\mathrm{p}_{1}\right)=\llbracket \lambda \mathrm{w}[\operatorname{raining}(\mathrm{w})] \rrbracket^{\mathcal{M}}\right)
\end{aligned}
$$

\footnotetext{
${ }^{10}$ Faller (2002: 200) calls (19) an "evidential version of Moore's paradox". However, this is somewhat misleading. In standard Moore's paradox sentences, e.g., It's raining but I don't believe $i t$, the second conjunct conflicts with something which is not properly part of the first conjunct, e.g., a norm of assertion. However, in sentences like (19), the second conjunct conflicts with a morpheme in the first conjunct: the evidential. Moore's paradox sentences can be true, but not be felicitously asserted - they are pragmatically odd, but not contradictions. Sentences like (19) can never be true. A closer English parallel with (19) would be It's raining, I believe, but I don't believe it.
} 
The evidential restriction in $\left(3^{\prime} \mathrm{ii}\right)$ reduces the input common ground $c_{1}$ to worlds where the speaker is certain that she did not hear $p$. The result is the set of worlds where the speaker heard $p$ but is also certain, based on direct evidence, that she did not hear $p$ - this is probably already an empty set of worlds.

Even if any worlds remain, the illocutionary relation in ( $3^{\prime}$ ii) is incompatible with $\left(3^{\prime} i\right)$. The illocutionary relation contributed by ( $3^{\prime}$ ii) orders worlds were the speaker did not hear $p$ (here, translated with the same predicate as the reportative, assuming it is a similar semantic relation) over worlds where the speaker heard $p$. However, all worlds in the common ground $c_{2}$, if there are any, are worlds where the speaker heard $p$, given the evidential restriction of $\left(3^{\prime} i\right)$. As a result, the relation will be necessarily empty - this is an incompatible sequence of updates.

One final observation is that the analysis proposed in this paper need not appeal to separate levels of semantic representation to distinguish the two contributions of evidentials. This simplifies the compositional semantics (see also Murray to appear). In addition, there are examples that show the two contributions of evidentials are not completely independent of each other. For example, consider Cheyenne (20), where the reportative in the second sentence is interpreted as anaphoric to part of the propositional contribution of the first sentence.

$$
\begin{array}{lllll}
\text { Éšee-va } & \text { ná-éestsėstov-o- } \varnothing & \text { Dale. } & \text { É-hó'tảheva-sėstse } & \text { Annie. } \\
\text { day-OBL } & 1 \text {-speak.to.s.o.-1:3-DIR } & \text { Dale } & 3 \text {-win-RPT.3SG } & \text { Annie }
\end{array}
$$

'Yesterday I spoke to Dale. [He says that] Annie won.'

More complex examples of the anaphoric properties of sentences with evidentials exist, see for example Cuzco Quechua (57) in Faller (2002: 69).

\subsection{Evidentials as Modals with an Evidential Presupposition}

Another approach to evidentials has been to treat them as modals with an evidential presupposition (e.g., Izvorski 1997, Matthewson et al. 2008). The evidential presupposition restricts the modal base to worlds where the speaker has the specified type of evidence for the scope proposition. This type of approach has been developed for evidentials that differ from parenthetical-like evidentials on some of the semantic diagnostics. For example, in St'át'imcets, which has modal-like evidentials, conjunctions like (2) are infelicitous (Matthewson et al. 2008). That is, the scope of the reportative must be (at least) an open possibility.

While there is genuine cross-linguistic variation in the behavior of evidentials, in all languages the evidential contribution is typically new information. It is thus problematic to analyze it as a presupposition, which is typically old information. Treating the evidential contribution as a presupposition predicts that evidentials should behave similar to, e.g., English verbs like learn, which presuppose their complement. However, this is not the case. It is odd to use verbs like learn with information that is not familiar or (discourse) old: \#John learned that the Earth is flat. Sentences with evidentials do not elicit this type of reaction, even though the speaker's source of information is typically not familiar or discourse old. 
Faller (2002) points out an additional empirical worry for this type of approach. Specifically, given the analysis in Izvorski (1997) evidentials should only be felicitous when the speaker does not know whether the scope proposition is true and judges her evidence source reliable. If the speaker does not think the source is reliable, or does not know, evidentials are infelicitous (\$3.5.2).

On the evidential presupposition approach and the illocutionary modifier approach, evidentials across languages, and even within a language, are very dissimilar sorts of things. There are real cross-linguistic differences in the behavior of evidentials, but there are also many commonalities. On the approach proposed in this paper, these differences can be expressed as a matter of detail, while treating evidentials as a natural semantic class. For example, take a language where sentences like (2) (Floyd won, I hear, but I'm certain he didn't) are infelicitous. A candidate translation for 'Floyd won-RPT' in such a language is (21):

$$
\begin{aligned}
& \lambda p\left[(p=\lambda w[\text { won }(w, \text { floyd })]) \wedge H R D\left(v_{0}, i, p\right)\right. \\
& \left.\quad \wedge \lambda w\left[\exists w^{\prime}\left(w R w^{\prime} \wedge p\left(w^{\prime}\right)\right)\right]\left(v_{0}\right) \leq \lambda w\left[\exists w^{\prime}\left(w R w^{\prime} \wedge p\left(w^{\prime}\right)\right)\right]\left(v_{1}\right)\right]
\end{aligned}
$$

The at-issue proposition and evidential restriction in (21) are the same as in $\left(7^{\prime}\right)$, the translation of a Cheyenne sentence with a reportative. Crucially, the illocutionary relation in (21) differs from $\left(7^{\prime}\right)$. It represents the proposal to add the possibility of $p$ to the common ground, where possibility is represented as existential quantification over worlds restricted by an accessibility relation (e.g., Kripke 1963). The translation in (21) is merely a first approximation, but it seems promising. The possibility of extending the proposed analysis to other languages deserves careful consideration and will have to be left for future research.

\subsection{Conventional Implicature (Potts 2005)}

Though Potts (2005) does not offer an account of evidentials, they share many properties with conventional implicatures (henceforth CIs), e.g., they are discourse-new, speaker oriented, and never take scope under propositional operators. However, Potts (2005) argues that CIs are "logically and compositionally independent" of the at-issue content (p. 11). This is not true of evidentials, and Amaral et al. (2007) argue there is actually more interaction between CIs and at-issue content than Potts (2005) predicts. Like Potts (2005), who proposes a multidimensional system, the analysis proposed in this paper is an attempt to model the at-issue/not-at-issue distinction. However, the ways of modeling this distinction diverge non-trivially.

Two questions come to mind. First, how would a treatment of evidentials look along the lines of Potts (2005)? As Amaral et al. (2007) point out, for Potts (2005), both the at-issue content and CIs end up contributing entailed propositions, which add the same kind of information to the common ground. Given this, it is not clear how Potts (2005) would account for data containing the reportative evidential, most crucially the felicity of (2). Furthermore, it is unclear how the analysis would account for the fact that the propositional contribution of sentences with evidentials is directly challengeable and negotiable while the evidential contribution is neither. 
In the analysis proposed here, this is a difference in the nature of the update, whether it reduces the common ground or imposes structure on it. Lastly, on a very general note, for Potts (2005) the two dimensions (at-issue and CI) are in principle logically and compositionally independent. Thus, it is not clear how the analysis would account for interactions between the two dimensions, such as the anaphora in (20). While the implementation used in this paper is not designed to model anaphora, the proposed analysis could be implemented in various frameworks.

Second, would the proposed analysis work for CIs? Take, for example, the sentence Tivi, who is a cat, enjoys chasing her tail, which contains a non-restrictive (supplemental) relative. The proposed analysis might be applied as follows. The relative who is a cat would contribute to the restriction, the not-at-issue component of assertion, which directly updates the common ground. (Above, I called this the 'evidential restriction', but it could be generalized.) This would account for the fact that the supplemental is not directly challengeable, like evidentials. The illocutionary relation, potentially contributed by declarative intonation, would represent the proposal to add the at-issue proposition, that Tivi enjoys chasing her tail, to the common ground. It remains to be seen to what extent the proposed analysis can account for the nuances of the data discussed in Potts (2005). But it would take into account the effect of CIs on the common ground, and so seems worth exploring.

\section{References}

Amaral, Patricia, Craige Roberts, and E. Allyn Smith: 2007, 'Review of The Logic of Conventional Implicatures by Chris Potts', Linguistics and Philosophy 30, $707-749$.

Bittner, Maria: 2008, 'Reportative Evidentials in Kalaallisut'. Ms. Rutgers. http://www.rci.rutgers.edu/ mbittner/.

Bittner, Maria: 2009, 'Tense, Mood, and Centering'. Ms. Rutgers. http://rci.rutgers.edu/ mbittner/.

Brasoveanu, Adrian: 2007, 'Structured Anaphora to Quantifier Domains: A Unified Account of Quantificational and Modal Subordination', in D. Leivant and R. de Queiroz (eds.), Proceedings of WoLLIC 2007. Springer-Verlag.

Faller, Martina: 2002, Semantics and Pragmatics of Evidentials in Cuzco Quechua, Doctoral Dissertation, Stanford.

Faller, Martina: 2006, 'Evidentiality Above and Below Speech Acts'. http://semanticsarchive.net/.

Gallin, Daniel: 1975, Intensional and Higher-Order Logic. North-Holland Publishing Company, Amsterdam.

Ginzburg, Jonathan: 1996, 'Interrogatives: Questions, Facts, and Dialogue', in S. Lappin (ed.), The Handbook of Contemporary Semantic Theory, 385-422. Blackwell Publishers, Oxford.

Groenendijk, Jeroen: 2009, 'Inquisitive Semantics: Assertions, Questions, and Hybrids'. http://sites.google.com/site/inquisitivesemantics. 
Groenendijk, Jeroen and Martin Stokhof: 1991, 'Dynamic Predicate Logic', Linguistics and Philosophy 14, 39-100.

Gunlogson, Christine: 2001, True to Form: Rising and Falling Declaratives as Questions in English, Doctoral Dissertation, University of California, Santa Cruz.

Hamblin, Charles L.: 1973, 'Questions in Montague English', Foundations of Language 10, 41-53.

Izvorski, Roumyana: 1997, 'The Present Perfect as an Epistemic Modal', in A. Lawson (ed.), Proceedings from Semantics and Linguistic Theory VII, 222239. Cornell University, Ithaca, NY.

Karttunen, Lauri: 1974, 'Presupposition and Linguistic Context', Theoretical Linguistics 1, 182-194.

Kripke, Saul A.: 1963, 'Semantical Analysis of Modal Logic I: Normal Modal Propositional Calculi', Zeitschrift für Mathematische Logik und Grundlagen der Mathematik 9, 67-96.

Leman, Wayne: 1980, A Reference Grammar of the Cheyenne Language, Occasional Publications in Anthropology, Series No. 5. Museum of Anhropology, University of Northern Colorado, Greely, Colorado.

Matthewson, Lisa, Hotze Rullmann, and Henry Davis: 2008, 'Evidentials as Epistemic Modals: Evidence from St'át'imcets', in J. V. Craenenbroeck (ed.), Linguistic Variation Yearbook 2007, Vol. 7. John Benjamins.

Murray, Sarah E.: to appear, 'Evidentiality and Questions in Cheyenne', in S. Lima (ed.), Proceedings of SULA 5. GLSA Publications, Amherst, MA.

Muskens, Reinhard: 1996, 'Combining Montague Semantics and Discourse Representation', Linguistics and Philosophy 19, 143-186.

Papafragou, Anna: 2006, 'Epistemic modality and truth conditions', Lingua 116, 1688-1702.

Potts, Christopher: 2005, The Logic of Conventional Implicatures, Oxford Studies in Theoretical Linguistics. Oxford University Press, Oxford.

Roberts, Craige: 1996, 'Information Structure in Discourse: Towards an Integrated Formal Theory of Pragmatics', Technical report, Linguistics Department, The Ohio State University, Columbus, Ohio. OSU Working Papers in Linguistics, volume 49, Jae-Hak Yoon and Andreas Kathol, editors.

Simons, Mandy: 2007, 'Observations on embedding verbs, evidentiality, and presupposition', Lingua 117, 1034-1056.

Stalnaker, Robert C.: 1975, 'Indicative Conditionals', Philosophia 5, 269-286.

Stalnaker, Robert C.: 1978, 'Assertion', in P. Cole (ed.), Syntax and Semantics 9: Pragmatics, 315-332. Academic Press, New York.

Stone, Matthew: 1997, 'The Anaphoric Parallel between Modality and Tense', Technical Report 97-06, University of Pennsylvania Institute for Research in Cognitive Science.

Stone, Matthew: 1999, 'Reference to Possible Worlds', Technical Report 49, Rutgers University Center for Cognitive Science. Update of Stone (1997).

Veltman, Frank: 1996, 'Defaults in Update Semantics', Journal of Philosophical Logic 25, 221-261. 